\title{
Scientific and Practical Basis for the Development and Design of a Management Model
}

\author{
Tannia Elizabeth Huertas López, Leonardo Manuel Cuétara Sánchez², \\ Bisleivys Jiménez Valero ${ }^{3}$, Wilson Fabián Criollo Erazo ${ }^{1}$
}

\author{
${ }^{1}$ School of Business Administration, University of the Armed Forces ESPE-ESFORSE, Ambato, Ecuador \\ ${ }^{2}$ Faculty of Business Administration and Economics, Technical University of Manabí, Portoviejo, Ecuador \\ ${ }^{3}$ Faculty of Engineering and Economics, University of Matanzas, Matanzas, Cuba \\ Email: thuertas@hotmail.es
}

How to cite this paper: Huertas López, T.E., Cuétara Sánchez, L.M., Jiménez Valero, B. and Criollo Erazo, W.F. (2019) Scientific and Practical Basis for the Development and Design of a Management Model. American Journal of Industrial and Business Management, 9, 1136-1156.

https://doi.org/10.4236/ajibm.2019.95077

Received: March 6, 2019

Accepted: May 11, 2019

Published: May 14, 2019

Copyright $\odot 2019$ by author(s) and Scientific Research Publishing Inc. This work is licensed under the Creative Commons Attribution International License (CC BY 4.0).

http://creativecommons.org/licenses/by/4.0/

(c) (i) Open Access

\begin{abstract}
The objective of this article is to contextualize the nature of management models and existing points of view, as well as the way in which they are developed or applied in the business context. The complex environment of current organizations requires flexibility to adapt to changing environment and achieve their objective with sustainable functionality, which is closely associated to their management. Furthermore, the most important approaches and trends that have proved effective management practice are identified; this could be done based on a brief historical account and extensive review of studies, which allowed reviewing and explaining the main management models as well as their elements of applicability. Afterwards, the elements for the specific design of a management model are determined to conclude that the characteristics of the mission, the elements of the culture, the complexity of the environment and the state of the technology determine the configuration of the management models, as well as, the methods and tools of planning, organization and control necessary for its implementation, evaluation and monitoring.
\end{abstract}

\section{Keywords}

Business Management, Management Models, Business Strategy,

Organizational Culture

\section{Introduction}

Society is an organizational conglomerate. Modern society has retained a high 
moral value of rationality, efficiency and effectiveness in contrast to the previous one. Society comprises relationships between individuals and organizations.

In turn, a theory is a discourse of relations between ideas within a set of border expectations and limitations. That theory is not more than a dialect device used to illuminate the difficult empirical scope. Thus, the objective of the theoretical statements is dual: train and communicate. Organizational theories instigate organizational practices and consequently aid practices (Blau \& Scott, 2003) [1].

Such organizations and society are needed and are subject to management. The progress of management, beginning with its development in the nineteenth century through several classical schools' domination, has been deployed through various approaches, along with a parallel progress of various exploratory aspects.

This research attempts to analyze the management models from their conceptualization until their development and application. It starts from the development of the most prominently used theories in the organization's management. The managerial conceptions had classic contributors, such as Frederick Taylor's scientific management, Henri Fayol's administrative process and Max Weber's bureaucratic management (Anheier, 2003) [2].

It is difficult to come to a clear understanding of management theories and models. The obstacles that tend to obstruct a unified vision of the theories are numerous and some seem impossible to overcome. The variety, discontinuity, fragmentation and heterogeneity of these studies characterize the current phase as a transition period, in which a strong paradigm as a point of reference is missing.

A clear lack of studies provides a crossover understanding of the theories from a non-historical perspective. This shortage is influenced by several reasons; one of them is the tendency towards the studies sectoring that clearly does not help the comparison and discussion of opposing theories (Bugdol \& Piotr, 2015) [3].

Additionally, even when considering theories that deal with similar problems and make research questions of this type, there is a lack of reciprocal understanding due to different hypotheses and domain assumptions about the subject.

This leads to the use of different measures and models that hinder comparison and expose them to continuous criticism and reassessment. This situation illustrates the state of organizational theories and how their evolution follows convergent and divergent ways (Blau \& Scott, 2003) [4].

The complexity currently faced by business institutions, characterized by a highly competitive environment, in which economic, technological, institutional, environmental and social globalization affects national and international trade, generates pressure for the corporations sectoral positioning, forging a determined and persistent activity for the dominance and conquest of the markets, favoring an increasingly intense competitive environment. Added to this reality 
is the replacement of the industrial era by a society where information and knowledge prevail (Hernández-Escobar, 2013) [5].

These factors have led corporations to consider scenarios in order to face these pressures and sustainably maintain their profitability, growth and presence in markets. This presence has generated development and implementation of strategies and tools such as the business management models, considering all the aspects and essential resources to make the corporate dynamics more efficient in the pursuit of the objectives and minimizing the risks.

Since the value's maximization has been established as the business north, all efforts to achieve it require timely and necessary decision-making, involving all the company's capabilities based on the impact on the business' strategic objectives (Martínez, 2013) [6].

In this order of ideas, the continuous and multiple changes occurring in the environment, demand continuous monitoring from corporations in order to redefine their strategies with the purpose of achieving a significant positioning in the national and international markets. This has led to assume the challenge of facing a contextualized environment due to the opening of markets, the increase in product diversification, rivalry of many competitors whose products and services with high quality standards are offered to clients in favorable conditions and circumstances due to their institutional image, trajectory and financial capacity (Gutiérrez \& Vidal, 2008) [7].

Some scholars do not exclude theories that tend to converge over time despite a strong initial differentiation. Other ones argue that the hypotheses diversity makes the set of even more fragmented organizational theories, which represents different paradigmatic worlds in which communication becomes impossible. Thus, it leads to the use of models and measures that make comparing more difficult.

It seems that we are in a classical pre-paradigmatic phase, where research and analysis are configured through search of anomalies and contradictions within the dominant theoretical frameworks, which in the absence of generally accepted and strongly institutionalized theoretical frameworks, creates an internal intellectual dynamic of theoretical struggle.

The evolution of the organizations theory usually begins with Taylor (1911) and Weber (1921), the so-called classical theorists. Although they had a different object of analysis (the Taylor's model arose from the factory production and the Weber's model from the public administration offices) both developed the same organizational principles such as the standardization of work, quality control and hierarchy.

Furthermore, both theorists strongly believed that the organizational models they proposed would prevail and eventually replace the other ones because they were the most efficient. Even though, the scientific management movement founded by Taylor largely shaped the industrial revolution and dominated the theory of organization in the 1930s, it is still very influential today. 


\subsection{The Management Models Contextualization and History}

In this sense, it is necessary to consider the contributions of Aguilar, Aguirre, Morantes, \& Espinoza (2002) [8], who highlighted that the business management models design has its historical justification in administration and management. They argue that various studies have proposed organizational models that contribute to institutional performance. These models are based on organizational charts with several levels of hierarchy.

Both strongly believed that the organizational models they proposed would prevail and eventually supplant all others because they were the most efficient. Although the scientific management movement founded by Taylor largely shaped the industrial revolution and dominated the theory of organization in the 1930 s, is still very influential today.

In this sense it is necessary to consider the contributions of Aguilar, Aguirre, Morantes, \& Espinoza (2002) [8] and Schmal \& Ruiz-Tagle (2009) [9], who point out that the design of business management models has its historical justification in the administration and management in the early twentieth century with the contributions of Frederick W. Taylor, on procedures to optimize efficiency and productivity and later with the contributions of Henry Fayol who established and associated the administrative processes of planning, organization, management, coordination and control to the management term. They argue that various studies have proposed organizational models that contribute to institutional performance, these models are based on organizational charts with several levels of hierarchy. Due to technological progress and global changes, the management of organizations has become complex due to the emergence of novel manifestations, perspectives, theoretical and conceptual referents, such as the virtualization of organizations, quality or continuous improvement and innovation, among others.

Aguilar, Aguirre, Morantes, \& Espinoza (2002) [8], argue that management is the main business dimension in which the constant need to understand and interpret the environment must be identified, thus changes can be projected on it and therefore respond to environmental demands through a Strategic management model. Moreover, it is mentioned that it is important for management to have models to evaluate the feasibility of planning beforehand in order to achieve the objectives and institutional goals. Finally, it is considered that, in order to decipher, understand and manage changes, it is essential to count on a work project that can be defined as a management model.

The previously cited authors conclude that, to make a change, it is not only necessary to have a model, but it also needs to be clearly defined, so that the company acquires a way of working that includes and integrates all the institution's capacities and willingness. Furthermore, they consider that a significant factor to be considered when designing a model is the ability to recognize, identify, interpret and understand the organization, which will allow the use of the strengths and make the necessary improvements to minimize the weaknesses. 


\section{Defining the Concept of Management Model}

The understanding of management model lies in the etymological origin of the term model which comes from the Italian "modello", therefore, it is a prototype that can be used as a reference to be produced; whilst management comes from the Latin "gestio", a word that adduces the action of administering (Navarro \& Llado, 2014) [10]. Therefore, it is a term widely used in the business world as an administrative prototype that allows the achievement of business objectives.

According to Cabezas (2018) [11], a model is a theoretical design of a system or a complex reality, which is developed in order to enable its understanding and study its behavior. Thus, it is considered that they represent real situations, elaborated at a certain scale and level of detail, to expose characteristic points of view of reality at a specific moment, with a view to interpret that reality in a simple and understandable way.

Cabezas (2018) [11], concludes that the models are adequate representations of real situations, modeled with a intention and points of view. This is essentially important because a model is created from the viewpoint of the person who formulates it, which indicates that a reality can be exposed or modeled from different perspectives even when what is intended to be represented is the same.

In this sense, Concari (2001) [12], argues that a model is conceived as a possible representation of a thing or event of general nature.

Navarro-Arvizu, Velasco-Cepeda, \& Esparza García (2015) [13], highlight that management is conceived as an administrative tool in charge of undertaking all the steps aimed at achieving some benefit for the organization, recognizing that the staff is an active resource and necessary to achieve institutional objectives. Whilst emphasizing that in an organization the management of human resources is the most significant and important: they deduce that the definition of management would be the "set of activities that develop, mobilize and motivate the employee staff a company needs for its success" (p. 12).

The same authors (citing López, 2014) state that a management model "allows establishing an approach in addition to an unbiased, rigorous and structured reference framework for the organization's diagnosis, as well as to determine the continuous improvement lines towards which the efforts should be oriented to" (p. 12).

Duque (2009), cited by Morantes-Higuera \& Acuña Corredor (2013) [14], when proposing the concept of management model, it is assumed as the way to organize and combine the organization's resources in order to meet the objectives; in other words, it is a set of principles, policies, systems, processes, procedures and behavior guidelines to achieve the expected results and improve the company's performance. These elements are framed through regulations, mission objectives, basic operating processes, structure and organization, organizational culture, policies and competencies of human talent and organization's formal strategic planning.

In this same order of ideas, Muñoz (2000) [15], considers that a management 
model is characterized by simplification of reality, eliminating certain features, factors, elements, functions or regularities; highlights certain features, factors, elements, functions or regularities; transparency, by simplifying and enhancing, facilitates that complex and unknown realities are transparent for their interpretation and analysis; perspectivity, greater meaning is given to the model by simplifying, framing it in a specific perspective; productivity, a model sets its own limits, favoring new research to update and improve it; abstraction, it implies an abstraction of the scientific view, indicating the relevant theoretical elements related to it; provisionally, the model is perfectible for improvements by virtue of scientific progress and research, as well as by comparison with other successful models of the organization's business sector; and finally and applicability, since it is intended to be applicable to a specific reality.

Navarro-Arvizu, Velasco-Cepeda, \& Esparza García (2015) [13], argue that management models are very different from each other, but all of them have attributable efficiency levels according to the type of company where management is practiced.

In this same order of ideas, Cabezas (2018) [11] defines a management model as the description and representation "of the administrative process that exists or will be implemented within an organization in order to organize the resources that will contribute to its sustainability" (p. 3).

An important contribution to be considered is Mondragon Corporation (2012) [16], who argues that a corporate management model aims to foster the development of a consistent business management dynamic. It goes along with institutional cooperation principles, supporting and helping to increase corporations' business competitiveness, making the corporate management style an identity brand that generates a sense of belonging. Thus, paving the way for cooperation and helping to optimize synergies at the institutional level.

Mondragon Corporation (2012) [16], adds that a management model is not an aesthetic or academic exercise, but rather a valuable tool to understand that its implementation will help companies to be more competitive in their operating markets. It will permit to have a shared reference at corporate level, which will undoubtedly allow a greater harmony in management as well as in leadership styles, although obviously, they do not seek uniformity, since each company has its own microclimate with its idiosyncrasies. It concludes that each corporation must interpret it, adapt it to its environment and offer its own approach to its application.

This conclusion is fundamental, since companies or a specific exercise intend to adapt many times a management model on it, by fully applying or fitting it. However, practice shows that each case may be different and therefore the model should be applied to the case, company, specific situation, either by adapting an existing model or creating a model that can be based on others or just a new idea and application.

The previously mentioned highlights the relevance of this research, which seeks to establish common parameters of the existing models, expand the pers- 
pectives for the creation of a model and establish the central aspects that must be considered to apply this fundamental tool in managerial administrative practice.

In this sense, following Cabezas (2010) [11], we agree that modeling the administration is somewhat complex since there is no exclusive format or outline of universal acceptance that embodies the multiple forms of human activity manifestation related to the organization and direction of the individual and collective work. However, there is enough evidence that management based on the criteria and scientific postulates of the administration can be represented as an integrated system capable of transforming the contributions of the workforce, property, plant and equipment, economic resources and the inputs for production, converting them into goods and/or services that are new and valuable to the community.

\subsection{Types of Management Models}

For Aguilar, Aguirre, Morantes, \& Espinoza (2002) [8], designing management models for organizations is a matter of importance, because it allows establishing the priority variables and the guidelines that will guide the organization; these variables include the inputs, processes and products needed to respond to the environment's demands and comply with the social function of the institution. By having the management model, the institutional project is established, the key elements are assumed to generate the organization's credibility and competence, clarifying the company's direction as well as the legitimacy of actions.

Díaz et al. (1997), cited by Aguilar, Aguirre, Morantes, \& Espinoza (2002) [8], explain that there are several referential models that illustrate institutional changes, as described in Table 1.

The types of management models are oriented to the strategic and organizational level. Thus, Frances (2006) [17], mentions that a business unit's balanced model integrates the strategic variables, the cause-effect relationship and its indicators, adding the levers of value and types of initiatives that will intervene in the value chain.

For Saracho (2005) [18], the model of generic competences lies in the labor motivation that relates the organization's interest to the employee in order to obtain benefits, therefore internally modify knowledge, motivations and behaviors to establish the profile line of each position.

Some models also focus on human resources management. Thus, Chiavenato (2012) [19], proposes a structure of subsystems that are based on improving the organization's productivity, where it is emphasized in the feeding, application, maintenance, development and control of human resources subsystems.

These exposed models are useful to know and describe organizations. However, they are insufficient as a guide for their integral management design; nevertheless, elements of each model can be chosen, and others discarded. In this regard, each organization will be responsible for designing its management model. It is important to note that the process of reviewing the management model of any company is within the processes of strategic planning and reengineering of 
it. The chosen management model will make it possible to structurally adjust the organization and adapt it to the demands that the strategic planning process itself is forging.

\section{Methods and Procedures}

In the elaboration of a management model, the proposal of methodological aspects raised by Rodriguez (2011) [20], should be considered, the management model should focus on three important columns in every organization: processes, human resources and technology. Only with these three pillars acting jointly and in a coordinated way, the organizational objectives can be reached, and therefore, they should be considered in the management models. In the same way, the author considers that the four main practices to consider in a management model are:

Table 1. Main management models that deal with functional changes in organizations.

\begin{tabular}{|c|c|}
\hline Types of models & Description \\
\hline Bureaucratic model & $\begin{array}{l}\text { It supposes the internal and external stability, where the members of the } \\
\text { organization assume a behavior following a linear and mechanistic logic. } \\
\text { In this model, changes are more in form than in the content. }\end{array}$ \\
\hline Evolutionist model & $\begin{array}{l}\text { Raised to allow the organization's development through an evolutionary } \\
\text { logic, so that the strongest characteristics survive. }\end{array}$ \\
\hline Cognitive mode. & $\begin{array}{l}\text { Based on the idea that the organization can learn and self-organize. Its } \\
\text { disadvantages are that it does not solve internal contradictions limiting } \\
\text { organizational growth, besides this model ignores the environment. }\end{array}$ \\
\hline Educational model & $\begin{array}{l}\text { Oriented by the construction of an organizational culture. It allows } \\
\text { defining patterns of interpretive reality and normally does not accept } \\
\text { external participation. }\end{array}$ \\
\hline Political model & $\begin{array}{l}\text { Based on processes, rules and other means of organization control, } \\
\text { considering the dynamics that mobilize the different interests, conflicts } \\
\text { and alliances in the organization }\end{array}$ \\
\hline Psychoanalytic model & $\begin{array}{l}\text { It focuses on behavior and control, emphasizing psychoanalysis in the } \\
\text { space of individuals and groups favoring the breakdown of conscious and } \\
\text { unconscious patterns that hinder the organization's advancement. }\end{array}$ \\
\hline Dialectical model & $\begin{array}{l}\text { It considers organizations as self-reproducing systems because of } \\
\text { opposite flows of positive and negative feedback, generated from the } \\
\text { dialectical logic where each phenomenon generates its opposite. }\end{array}$ \\
\hline Hegemonic model & $\begin{array}{l}\text { Its essence is based on power, where certain people impose their will on } \\
\text { others. This situation results in groups of exploitative employers and } \\
\text { exploited employees. }\end{array}$ \\
\hline Relational model & $\begin{array}{l}\text { It considers the organization as a multidimensional space with networks } \\
\text { of formal and informal relationships articulated by dynamic processes. In } \\
\text { this sense, organizations are not independent and relationships inside } \\
\text { and outside of it can generate conflicts and disagreements where the best } \\
\text { mechanism par excellence to face them is negotiation. }\end{array}$ \\
\hline Strategic model & $\begin{array}{l}\text { It conceives the organization as an entity created and financed by society } \\
\text { for its development, integrated by networks of internal and external } \\
\text { relations. It also, considers and makes changes in its environment. }\end{array}$ \\
\hline
\end{tabular}

Source: Aguilar, Aguirre, Morantes, \& Espinoza (2002) [8]. 
- The strategy. Key aspect to keep the company focused on its corporate business strategies, fostering continuous growth.

- Execution. The fulfillment of the established objectives, exceeding them in the possibility of an excellent execution of the operations.

- Culture. The creation of a culture strongly inspired by good performance over any other option should be favored.

- Structure. A horizontal structure that favors flexibility and speed should be encouraged as much as possible in order to implement the proposed changes in the management model. Successful companies are flexible and dynamic because they readily accept and accept the elementary changes to attenuate the structural bureaucracy and facilitate the work, establishing objectives on the go.

The formulation of management models requires a process that begins with the study of the variables that comprise it, subsequently, the stakeholder is consulted, then it continues with the model's written statement and ends with the recognition, acceptance and in accordance with the final report (Cabezas, 2010) [11]. In this section of our analysis, we consider two approaches to the development of management models: the one proposed by Cabezas (2010) [11] and the one by Mondragon Corporation (2012) [16].

Figure 1 shows the processes of developing the management model, complying with four approaches or moments: prospecting, negotiation, formulation and review.

These processes are explained and detailed as follows:

Prospecting stage: In this phase, the necessary research is carried out in order to identify and understand the variables that delimit and define the model. It includes the analysis that allows defining the base line on which the model is formulated and that will later be known as a diagnosis.

Negotiation stage: This phase consists of opinions query and convictions with the actors who have significant influence for the proposal achievement or failure. Key actors are considered "public services or their officials, private institutions or their leaders, political leaders and social actors" (Cabezas, 2010, p. 5) [11].

It is advisable not to formulate a management model by dismissing these actors, or by excluding the participation of those who will oversee its implementation and execution. It is essential and necessary to consider the opinion of all those who, due to their significant influence, can affect its functioning. For this reason, direct consultations or mechanisms of mass participation should be implemented.

It is important to clarify that the actors' opinion and especially that expressed by the community are not necessarily binding but constitute a resource for the reasonable and acceptable management model preparation.

Formulation stage: The formulation is the drafting process in a comprehensible way and with the dimensioned and acceptable use of the concepts of the proposed management model. 


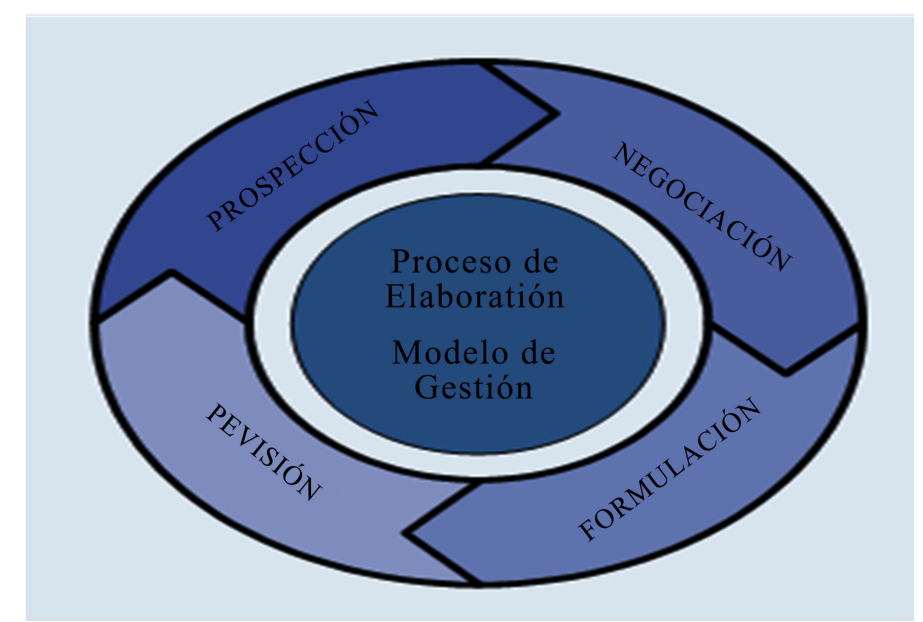

Figure 1. Management model elaboration process. Source: Cabezas, 2010.

Reviewing stage: The process of elaborating the management model ends with the review and subsequent approval of the formulation. This stage may include several revisions depending on the complexity of the model and the actors involved.

It is a model that is used to establish administrative guidelines based on the organization's financial resources, for which the stages of prospecting, negotiation, formulation and revision are traversed.

\subsection{Mondragon's Corporate Management Model}

The Corporate Management Model (CMM) is expressed through a circle that rotates permanently, which seeks to disseminate the relationship of the various elements in groups and the energy required for its applicability and continuous adaptability.

In this sense, Mondragon Corporation (2012, p. 13) [16] states: "In the center of the graph, and as a starting point, are the Basic Cooperative Principles, which provide behavioral guidelines to People in Cooperation to put into practice the values of the Cooperative. These people are the ones who build a Shared Project and endow it with a Participatory Organization to put it into practice".

This management model considers the company in a competitive market environment with all its components. Although the cooperative fact facilitates advantages in the implementation of the most advanced concepts in management, it is necessary to put them into operation to become an excellent company.

The achievements made establish the main point of evaluation of the effectiveness of the application of the CMM. In this order of ideas, there are no excellent companies with poor results; therefore, it is essential to set up an acceptable control panel, selecting the appropriate indicators to show the scope of good socio-entrepreneurial results.

Figure 2 shows the outline of the corporate management model established by Mondragon Corporation with a comprehensive approach. 


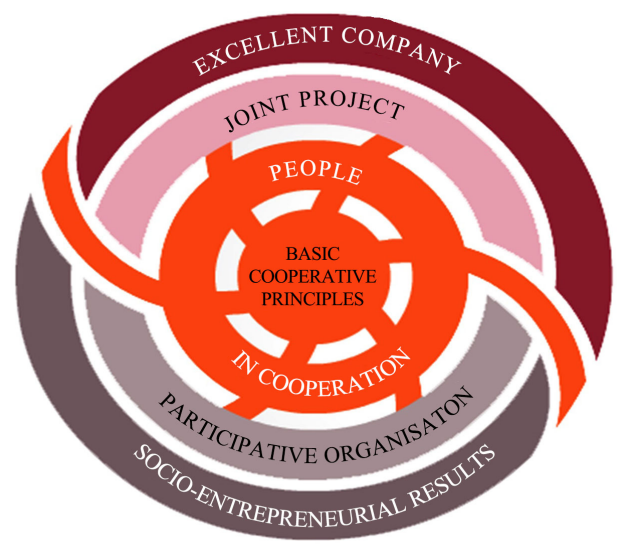

Figure 2. Corporate management model. Source: Mondragon, 2012.

\subsubsection{Degree of Complexity in the Management Model Development}

The degree of complexity in the management model development is determined by the several conditioning variables of the administrative procedures, and the degree of comprehension and the cosmovision reached on the variables.

Under this consideration, the more confused, unknown and the lower the level of knowledge about the variables, the previous research will require greater efforts and therefore the formulation of the model will be more complex.

A critical reading of what is presented in this regard is that a model is considered complex when it has multiple variables to consider in its formulation or when these are unknown.

In this sense, Cabezas (2010) [11] explains that it is assumed that a complex management model will have a design cycle that will be extended in the prospecting and negotiation phases, because it will require the development of rigorous studies to recognize the best option. According to the complexity of the model, the contribution of expert consulting firms will be required to promote research and possible representation of the management model, with the approval of the products delivered to the top management of the organization.

Likewise, a model will be considered moderately complex when only some of the variables to be considered are unknown by the team that is formulating the model. A management model is basic when all the variables to be considered are known by the stakeholder groups. For this reason, it is presumed that the phases of prospecting and negotiation will be undertaken in a short-term. It is a model that is used as part of continuous improvement, the same ones that ensure the organization's sustainability, therefore it uses systems based on variable TPS and GMS that allow to increase the organization's profitability and facilitate the transfer of knowledge.

\subsubsection{European Model of Business Innovation}

Figure 3 shows the model that was born from the European Forum and part of the innovation and the organization's life cycle, assuming the so-called innovation triangle. 


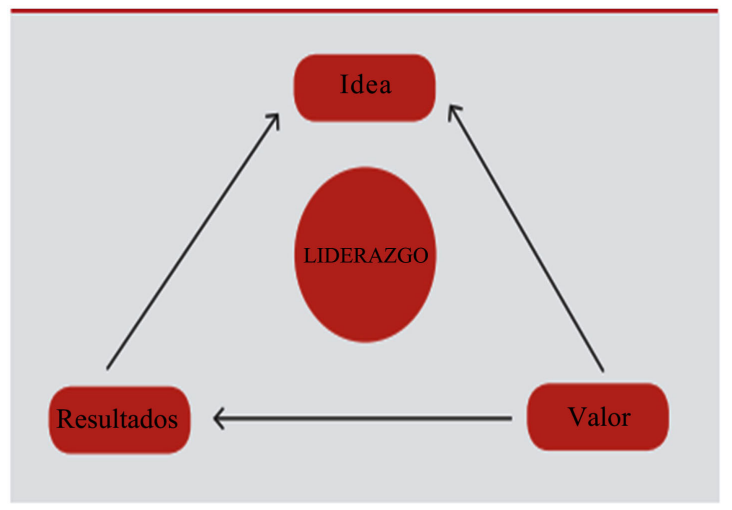

Figure 3. European model of business innovation. Source; Martínez, 2013.

To establish this model, it is necessary to use several activities and functions in order to achieve the objectives: strategic business management, innovation management, operation management, finance and control, leadership, organization and people management, external communication and marketing and values respectively.

It is a model that requires the company's commitment since each activity needs modifications and the establishment of guidelines to achieve synergy and innovation.

The model is aimed at creating an efficient and effective organization that can take risks and facing challenges, for which lie management bases that allow creating the synergy between the processes and activities, thus achieving the objectives set within the organizational structure.

\subsubsection{Werther and Davis' Management Model}

The management model is developed by activities and subsystems that are directly related throughout the model in which purposes and requirements are established in order to contribute to generate feedback.

This model is based on corporate objective, social objectives and personal goals. It is constituted by the following subsystems: foundations and challenges, preparation and selection and development and evaluation. The structure of the model allows the establishment of integral guidelines for staff planning, which are based on objectives (Werther \& Davis, 2000) [21].

\section{Results and Discussion}

\subsection{Structure of a Management Model}

The structure of a management model must describe how to negotiate and optimize in a real and continuous way all the processes involved in the planning, programming and execution of it, contemplating a real operational context. Each stage of the model corresponds to an action that precedes the subsequent, being the order and meaning of the proposed actions in the single and non-invertible model (Viveros, Stegmaier, Kristjanpoller, Barbera, \& Crespo, 2013) [22]. 
Among the components that distinguish the structure of a management model, the management framework is identified as detailed in Figure 4, in paragraphs below; shows the structure of a management model, which will be explained as follows.

The description of each of the aspects detailed in the structure of the management model is explained below:

Management framework: This part of the structure must be considered as the introductory framework of the whole model, it presents all the previous antecedents, the type of the proposed model is identified and described, and a synthesis of the main variables that may influence its administration is provided.

It is important to consider that the management framework is not the complete diagnosis' transcription or preliminary studies, but a conclusive compendium of the most important aspects obtained from them. This framework should not constitute an extensive preamble that finishes eclipsing the other modules and exhausting readers because of its wide content.

Management plan: The management plan is the administration's platform "because it defines the concrete actions to be implemented to lead the present towards a future with anticipated purposes, in other words, the plan is the guiding framework that allows to anticipate the facts, the circumstances, and to work with the idea. It is not so easy to accept, that the future is not born, but it is made; it is created" (Cabezas, 2010, p. 13) [11].

The plan is embodied in a manuscript that clearly and precisely formulates what is intended to be achieved, the opportunity to achieve it, and how to achieve it.

The management plans are constructed by coherently coordinating and connecting as a set of objectives, goals and activities with each other, forming the leading guide that facilitates reaching the future proposed through the allocation of resources, time and those responsible.

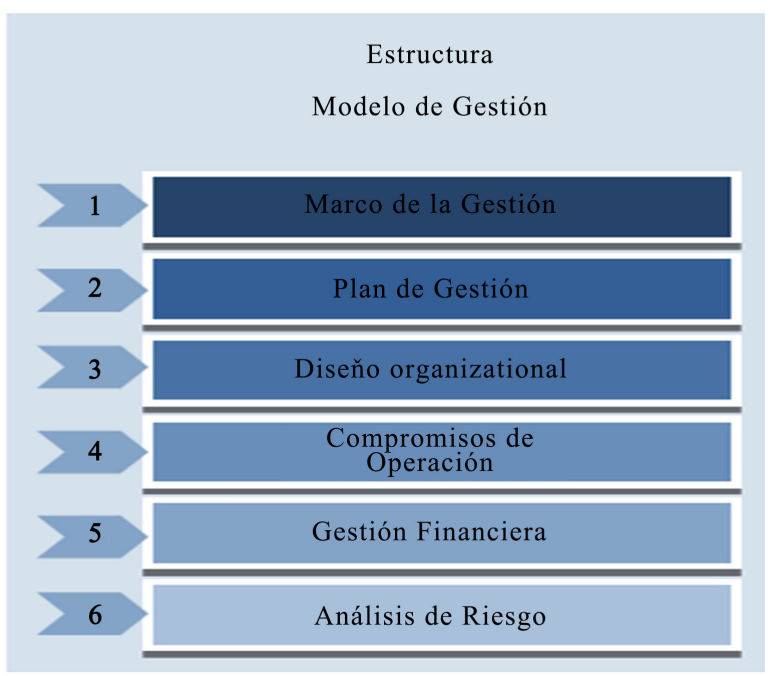

Figure 4. Structure of a management model. Source: Cabezas, 2010. 
In order for the management model, through its organization and functioning, to be fully operational, it must determine which mechanisms will supply the inputs, production, distribution, equipment, customer service, and other tools and information flows which are necessary for its implementation (Ministry of Public Health, 2013) [23], (Cano-Olivos, Orue-Carrasco, Martínez Flores, Mayett-Moreno, \& López-Nava, 2015) [24].

It can be characterized as a multidisciplinary, participatory, iterative tool, in which the purpose is to agree on a common vision of the future organization's development, defining the objectives to achieve that vision, determine the activities to be implemented, recognize the actors involved, establish the goals related to the various activities and specify the modalities for monitoring through indicators.

Organizational design: It is the design assumed by the management model, it will identify the organizational and functional structure that the organization will assume, the structure of positions for each function, the hierarchical relationship between them, the responsibilities and the assigned faculties. The way in which the relationships with the relevant actors will be manifested and described, besides, the coordination to be adopted with the interest group will be described.

Operation commitments: The management model must include all the agreements and commitments derived from each phase of the formulation, implementation and control of the organization's management model. The responsible for the commitments' fulfillment must be identified, allocating the resources and time for it.

Financial management: Once the operational commitments have been identified, the economic value is assigned for their implementation. Then, it is necessary to specify the volume of income to be generated in order to afford the commitments. Costs should be estimated based on the expense involved to achieve the activities agreed in the operating contracts. The usual costs in any model are: salary compensations, equipment, raw materials, basic services, among others. The estimated income must consider all the sources of its origin.

Risk analysis: At the end of the formulation of the management model, an overview of those factors that could hinder, impede and diminish the scope of the corporate objectives must be generated. Besides, all measures must also be presented to face these obstacles, in the same way; all the possible key factors of success must be presented, so that if during the implementation of the management model these are presented, they must also show the necessary actions that are advisable to promote and to generate their presence.

\subsection{Basic Aspects That a Management Model Contains}

An adequate management model (Boy, 2012) [25] must capture both an "inside-out" analysis (that is, inside the company) and an "out-of-company" analysis (viewed from the point of view) view of external stakeholders. 
Make sure that not only all the potential issues (the "points") are identified, but also the points are connected in a way that helps to recognize the links and take measures to prevent current or potential crises. The process of implementing a management model, according to Blau \& Scott (2003), begins with an evaluation of both the intrinsic issues (for example, labeling of packaging in a food manufacturing business) and any consideration of emerging problems.

These are the points the areas that can lead to the recognition of potential risk or an opportunity for the company. To identify them, a scan of the problems is required (for example, going through the specialized press, scientific literature, analysts' research, print and broadcast media, blogs, regulatory releases, among others) among other actions (Bugdol \& Piotr, 2015) [26].

There are many other important emerging aspects that derive from the company itself, such as the focus of the company's management team (and the way in which its priorities may change), which are often embodied in the company's mission, vision and its declaration of values. Furthermore, other considerations must also be considered, they come from: priority elements and opportunities intrinsic to the business; compliance risks; policies, legal framework and reputational risks, opportunities and trends; In addition, the critical expectations of society and the company.

Of course, many companies have well-developed processes to articulate each of these considerations. The points are identified; however, they are not often connected to each other. For example, the I \& D area could be aware of a trend in biotechnology that still does not rise to the level of corporate planning. But, in terms of public policies or relations with the government will become an unavoidable challenge for the business in the future. There is where the management model comes into play. In order to ensure that the correct problems are being attacked and the situations are properly prioritized so that they can be managed effectively, a work team must be formed that can be multidisciplinary.

The team must analyze the impact and urgency of the potential issues in order to develop a set of elements to be managed by the company. These elements, in turn, inform and form numerous decisions and corporate responses, for example, the use of a new technology and its possible benefits and possible risks for the business.

This, in the opinion of Been-Lirn, Lee, Pei Luen, \& Mu Qing (2016) [27], could trigger:

- A set of policies and procedures that govern how the new technology will be integrated with respect to existing processes and products;

- Internal systems to implement, measure and monitor the compliance of the new guidelines and practices;

- New positions and messages that the company will need to articulate, interact with new actors and communicate with different audiences;

- A revised agenda of public policies and defense.

As the company begins to interact on all fronts, both internally and externally, then management feedback will address issues such as: types of risks and busi- 
ness opportunities; the identity and the protagonists and antagonists' reasons; with a better understanding of the expectations of key company's stakeholders. All this information is fed back into the management process and the cycle begins again.

\subsection{How to Formulate a Management Model}

The formulation of a management model is largely based on the conceptual structuring practices used in the design of information systems, especially those related to databases (Blau \& Scott, 2003) [4].

A retrospective approach to structured design is proposed in the general context of the conventional management model, suggesting ways in which structured modeling and the model may be relevant today. Modeling plays a central role not only in the disciplines of operational research and management sciences, but also in the process of analysis and design of information systems. In fact, modeling and simulation have become the third pillar of scientific research, as well as theory and experimentation. However, although the models are apparently excellent pieces in so many areas of intellectual effort, they often seem to have no sense of urgency in cataloging and managing the processes, contents, assumptions, results and impacts that are inherent to them (Boy, 2012) [25].

The model management's inability to catch the target audience's attention, particularly organizations and associated decision makers who could benefit most from it, and suffer more from its absence, is a curious phenomenon. It is worth wondering if the times have not yet shown the benefits of this opportunity, or if there is a deeper cultural rift that leaves the art and practice of formulating management models behind ordinary day-to-day organizational concerns (Bugdol \& Piotr, 2015) [26].

These elements that are summarized below have been formalized in Geoffrion's modeled representation approach (1989), which is defined as a semantic framework to represent a wide range of models, mainly from the domain of scientific research and management operations. Although many of the applications that structured modeling poses are circumscribed in the research literature tending to optimization models.

In this sense, this approach had great difficulty in demonstrating that models from a wide range of domains, some outside of operations research or from management sciences, could be represented by using structured modeling.

In any case, the management models must start from an understanding of the key parts of an organization. Mintzberg (1992) explains them in the following way:

- The strategic apex is the senior management and its supporting staff;

- The operational core is the workers who develop the organizations' tasks;

- The middle line of intermediate and lower level;

- The technostructure is analyst such as engineers, accountants, planners, researchers and personnel managers; 
- Support personnel are people who provide indirect services;

- The second basic dimension of an organization is its main coordination mechanism, which includes the following (Mintzberg, 1992) [28];

- Direct supervision: means that an individual is responsible for the work of others. This concept refers to the command unit;

- The normalization of the work process: it exists when the work content is specified or programmed;

- Standardization of skills: when the type of training necessary to perform the job is specified;

- The standardization of production: when the results of the work are specified;

- Mutual adjustment: when work is coordinated through informal communication.

The third basic dimension of an organization is the type of decentralization that employs or combines the following three types of decentralization:

- Vertical decentralization: the distribution of power in the chain of command, or the shared authority between subordinates and supervisors in any organization;

- Horizontal decentralization: the measure in which non-administrators (including staff) make decisions or share authority between managers and staff,

- Selective decentralization: it is the extent to which the power of decision is delegated to different units within the organization.

From the structuring and functioning of these three basic dimensions (the key parts of the organization, the coordination mechanism and the type of decentralization), then the strategy adopted by an organization and the degree to which that strategy is put into practice. It can result in five structural configurations: simple structure, machine bureaucracy, divisional form and adhocracy.

Similarly, some authors argue that the formulation of management models has a life cycle composed of (Blau \& Scott, 2003) [4]:

- The problem Identification: it is like the specifications of requirements in the development of information systems, where the needs of the user or client, the objectives of the model and the data sources are identified;

- The creation of the model involves the formulation of a model's conceptual representation. Normally, for the operations research models or the management sciences, this representation consists of a description of the problem;

- However, as it will be evidenced in the structured modeled, a conceptual model that subsumes the description as one of the many opinions of global representation in a desirable objective;

- The formulation can reuse an existing description or a composition of two or more of them already established, subject to revision and modification;

- The model implementation is the development of a computerized executable of the model representation, either through the development of ad hoc pro- 
grams or, preferably, by using existing languages and modeling environments. Also, critically, this stage includes the identification, data's collection and quality control that will feed the model;

- The model's solution requires the identification of an appropriate solution algorithm, the preprocessing data provides information to the solver and delivers results to the database, sequencer and executor;

- Model interpretation: involves the analysis of the results, understanding and socialization of the model, making the consequent sensitivity analysis;

- The distribution and application of the model refers to the process of making an operational model accessible to the user community based on a need for knowledge. The functions of critical mission in this sense are the security of the data and the model, in the middle of the Internet era with its guarantee of information;

- The evolution of the model: the model versions that reflect different sets of assumptions and data that can proliferate rapidly and must be handled carefully. This can result in a reformulation of the model, which causes additional iterations through the life cycle process;

- Validation of the model: it is a persistent process that occurs throughout the life cycle. This can vary from the analysis of dimensional and unitary consistency in the formulation stage, to the traditional processes of internal and external validation in the solution and interpretation that the solution of the model is consistent with that of the assumptions and the "real world".

All the elements must be considered and adapted in a flexible and contextualized manner for the elaboration and implementation of the management model that each organization needs and demands.

\section{Conclusions}

From it development, the theoretical aspects analyzed including, the types, approaches, main characteristics, structure and elements that are included, as well as the formation of a management model, are described below a series of conclusions referred to:

1) Formulating management models is not an easy task, because each organization has its personality based on its own reality as a company faced with an environment that pressures and conditions it. To face this highly competitive scenario, organizations use tools to model their management. To do this, they investigate all the variables of reality that could affect their behavior and subsequent positioning and represent them in models, which after a series of phases culminate with their validation.

2) The complexity of the management models will depend on the variables considered and investigated, as well as, the knowledge that they have. However, one of the advantages of management models is that in their elaboration; all institutional capacities are considered and included with a view to generating a strategic way for the successful achievement of the institution's future. 
3) The management models are as varied as the organizations' needs, so it is necessary that each company according to its features choose and implement its own depending on the circumstances and needs; what is relevant is that at the time of its formulation and implementation, all the interest groups, both internal and external, are included and considered in order to assess their appreciations in this regard.

4) Therefore, it is essential to configure the management models that include all the aspects closest to the organization's environment and select the appropriate indicators to demonstrate the scope of good business results.

5) A crucial aspect is to understand the organizational dimensions and their key importance to communicate the model, in terms of this work, distribute it and validate it. The control devices and evaluation methodologies are equally important, the management model is only sustainable and adaptable to the changing reality if it is possible to identify its failures in time and have the management tools to do so.

\section{Translated to English by}

Wilson Fabian Criollo Erazo, wilsonfabice@hotmail.com, University of the Armed Forces ESPE-ESFORSE, Ambato, Ecuador.

Harold Giovanni Lopez Urquizo, B.B.A., Lopez23@bellsouth.net, Florida International University-Miami, Florida, USA.

Mailé Salgado Cruz, maile.cruz@umcc.cu, Faculty of Engineering and Economics, Matanzas University, Matanzas-Cuba.

Eliseo Suarez Garcia, Faculty of Physical Education, Matanzas University, Matanzas-Cuba.

\section{Conflicts of Interest}

The authors declare no conflicts of interest regarding the publication of this paper.

\section{References}

[1] Blau, P. and Scott, R. (2003) Formal Organizations: A Comparative Approach. Stanford University Press, Stanford, CA.

[2] Ben-Her, A. and Gui, B. (2003) The Study of Nonprofit Enterprise: Theories and Approaches. Springer Science \& Business Media. https://www.researchgate.net/publication/268050988_The_Theory_of_Nonprofit_O rganizations_Revisited

[3] Bugdol, M. and Jedynak, P. (2015) Integration Approach in Modern Management Concepts. In: Bugdol, M. and Jedynak, P., Eds., Integrated Management Systems, Springer Publishing, Cracovia, 83-127. https://doi.org/10.1007/978-3-319-10028-9_3

[4] Blau, P.M. and Scott, W.R. (2003) Formal Organizations: A Comparative Approach. Stanford University Press, Stanford, CA.

https://www.researchgate.net/publication/40421879_Formal_Organizations_A_Co mparative_Approach 
[5] Hernández-Escobar, J. (2013) Modelo de gestión empresarial según nuevas tendencias: Intangibles y calidad total. Aplicación al sector camaronero de Venezuela. Universidad de Córdoba, Córdoba, España.

[6] Martínez, Á. (2013) Desarrollo y definición de un modelo de gestión como paso previo para la innovación empresarial. Calidad, enero-marzo, 42-46.

[7] Gutiérrez, V. and Vidal, C. (2008) Modelos de gestión de inventarios en cadenas de abastecimiento: Revisión de la literatura. Revista Facultad de Ingeniería Universidad de Antioquia, 43, 134-149. http://www.redalyc.org/html/430/43004313/

[8] Aguilar, J., Aguirre, I., Morantes, W. and Espinoza, Y. (2002) Metodología para la elaboración de un modelo de gestión en una institución pública venezolana: Fundacite-Mérida. Interciencia, 27, 293-298.

[9] Schmal, S.R. and Ruiz Tagle, A. (2009) Un modelo para la gestión de una escuela universitaria orientada a la formación basada en las competencias. Cuadernos de Administración, 22, 287-305.

[10] Navarro, M. and Llado, D. (2014) La gestión escolar: una aproximación al estudio. Fondos Mixtos CONACYT. Gobierno del Estado de Tamaulipas, 189. https://scholar.google.com/citations?user=4Gl39KcAAAAJ\&hl=es

[11] Cabezas, C.C. (2018) Guía metodológica para la elaboración de modelos de gestión del patrimonio cultural inmueble. Santiago de Chile: Ministerio del Interior, Subsecretaría de Desarrollo Regional y Administrativo, División de Desarrollo Regional, Dpto. Gestión de Inversiones Regionales, Gobierno de Chile, 61. https://www.gorecoquimbo.cl/gorecoquimbo/site/artic/20180806/asocfile/20180806

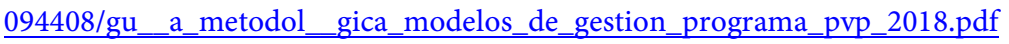

[12] Concari, S. (2001) Las teorías y modelos en la explicación científica: implicancias para la enseñanza de las ciencias. Ciência \& Educação, 7, 85-94.

http://www.scielo.br/pdf/ciedu/v7n1/06.pdf https://doi.org/10.1590/s1516-73132001000100006

[13] Navarro, E.M., Velasco-Cepeda, R.I. and Esparza-García, I.G. (2015) Metodología para diseñar un modelo de gestión para mejorar el desempeño individual en una organización de la sociedad civil de Ciudad Obregón, Sonora. Instituto Tecnológico de Sonora, Durango, 224.

https://www.itson.mx/publicaciones/Documents/tesis-doct/tesiselbamyriam.pdf

[14] Morante-Higuera, A. and Acuña-Corredor, G. (2013) Propuesta de modelo de gestión para educación superior a distancia: una aproximación. Zona Próxima-Revista del Instituto de Estudios en Educación Universidad del Norte,18, enero-junio, 21. http://www.scielo.org.co/pdf/zop/n18/n18a07.pdf

[15] Muñoz, A. (2000) Hacia una educación intercultural: Enfoques y modelos. Universidad Complutense de Madrid. Encuentros de educación, 101-135. https://revistas.ucm.es/index.php/RCED/article/viewFile/RCED9898220101A/17334

[16] Mondragon Corporation (2012) Modelo de gestión corporativo, 76. https://www.mondragon-corporation.com/wp-content/uploads/2017/Modelo-de-ge sti\%C3\%B3n-Corporativo-MONDRAGON.pdf

[17] Francés, A. (2006) Estrategia y planes para la empresa y cuadro de mando integral. IESA: Pearson Prentice Hall, New Jersey, 507.

https://books.google.com.ec/books/about/Estrategia_y_planes_para_la_empresa.ht ml?id=yAmLG-Vr8BkC\&redir_esc=y

[18] Saracho, J.M. (2005) Un modelo de gestión por competencias. RIL Editores, Santiago de Chile, Chile, 275. 
https://www.marcialpons.es/libros/un-modelo-de-gestion-por-competencias/97895 $62844321 /$

[19] Chiavenato, I. (2012) Gestión del talento humano. McGRAW-Hill/Interamericana Editores, S.A. DE C.V. Tercera edición, 626.

http://www.facso.unsj.edu.ar/catedras/ciencias-economicas/administracion-de-pers onal-I/documentos/chiavena.pdf

[20] Rodríguez, G.J. (2011) La importancia de un adecuado modelo de gestión y su correlación con la estrategia, el gobierno corporativo y la gestión decambios.

https://es.slideshare.net/jorgergrecco/alineacin-del-modelo-gestin-con-la-estrategia -el-gobierno-corporativo-y-la-gestin-del-cambio. https://doi.org/10.4272/978-84-9745-510-7.ch5

[21] Werther, J.W. and Davis, K. (2000) Administración de personal y recursos humanos. México.

[22] Viveros, P., Stegmaier, R., Kristjanpoller, F., Barbera, L. and Crespo, A. (2013) Propuesta de un modelo de gestión de mantenimiento y sus principales herramientas de apoyo. Ingeniare. Revista chilena de ingeniería, 21, 125-138.

https://scielo.conicyt.cl/scielo.php?script=sci_arttext\&pid=S0718-33052013000100011 https://doi.org/10.4067/s0718-33052013000100011

[23] Ministerio de Salud Pública (2013) Guía para la elaboración de modelos de gestión, organización y funcionamiento de los servicios del MSP. Coordinación general de gestión estratégica. Ministerio de Salud Pública, Quito.

http://instituciones.msp.gob.ec/somossalud/images/documentos/guia/Guia_para_la EElaboraci\%C3\%B3n_de_Modelos_de_Gestion_Organizaci\%C3\%B3n_y_Funciona miento.pdf

[24] Cano-Olivos, P., Orue-Carrasco, F., Martínez-Flores, J.L., Mayett-Moreno, Y. and López-Nava, G. (2015) Modelo de gestión logística para pequeñas y medianas empresas en México. Contaduría y Administración, 60, 181-203.

file://C:/Users/leona/Downloads/8-8-1-PB.pdf https://doi.org/10.1016/s0186-1042(15)72151-0

[25] Boy, G. (2012) Organization Design and Management. In: Boy, G., Ed., Orchestrating Human-Centered Design, Springer Publishing, Miami, 117-138.

https://www.springer.com/gp/book/9781447143383

https://doi.org/10.1007/978-1-4471-4339-0_6

[26] Bugdol, M. and Jedynak, P. (2015) Integration in Different Organizational Situations. In: Bugdol, M. and Jedynak, P., Eds., Integrated Management Systems, Springer International Publishing, Cracovia, 161-192.

https://www.springer.com/us/book/9783319100272

https://doi.org/10.1007/978-3-319-10028-9_5

[27] Duh, H.B.-L., Lee, J.-J., Rau, P.L.P. and Chen, M.Q. (2016) The Management Model Development of User Experience Design in Organization. In: Duh, H.B.-L., Lee, J.-J., Rau, P.L.P. and Chen, M.Q., Eds., Cross-Cultural Design, Springer Publishing, Sidney, 163-172.

[28] Mintzberg, H. (1992) Estructura en cinco: Diseño de organizaciones eficaces. Prentice Hall Editorial, New Jersey, 130.

https://tecnoadministracionpub.files.wordpress.com/2016/08/u2-mintzberg-e28093 -disec3b1o-de-organizaciones-eficientes.pdf 